\title{
Pengaruh Self Esteem, Kompleksitas Tugas, dan Ketidakpastian Lingkungan Pada Senjangan Anggaran
}

\author{
I Dewa Ayu Diah Nirmala Dewi ${ }^{1}$ \\ A.A.G.P. Widanaputra ${ }^{2}$ \\ ${ }^{1,2}$ Fakultas Ekonomi dan Bisnis Universitas Udayana (Unud), Bali, Indonesia \\ e-mail: dewaayudiah12@gmail.com
}

\begin{abstract}
ABSTRAK
Tujuan penelitian ini adalah untuk memperoleh bukti empiris pengaruh self esteem, kompleksitas tugas, dan ketidakpastian lingkungan pada senjangan anggaran di Hotel Berbintang Wilayah Nusa Dua. Penelitian ini dilakukan pada hotel bintang 3, 4, dan 5 di Wilayah Nusa Dua. Sampel yang digunakan sebanyak 234 manajer menengah pada hotel bintang 3, 4, dan 5 di Wilayah Nusa Dua dengan menggunakan metode purposive sampling dan teknik analisis data yang digunakan adalah analisis regresi linear berganda. Pengumpulan data penelitian ini dilakukan melalui penyebaran kuesioner. Berdasarkan hasil penelitian ini, ditemukan bahwa self esteem yang dimiliki oleh manajemen hotel cenderung rendah dan ketidakpastian lingkungan yang dihadapi juga rendah sehingga hal ini akan dapat menyebabkan terjadinya senjangan anggaran. Kompleksitas tugas yang dialami oleh manajemen hotel pun cenderung tinggi sehingga hal ini juga dapat menyebabkan terjadinya senjangan anggaran.

Kata kunci: Selfesteem, kompleksitas tugas, ketidakpastian lingkungan, senjangan anggaran.
\end{abstract}

\begin{abstract}
The purpose of this study is to obtain empirical evidence of the effect of self esteem, task complexity, and environmental uncertainty on budgetary slack in the Nusa Dua Region Star Hotels. This research was conducted at 3, 4 and 5 star hotels in the Nusa Dua Region. The sample used was 234 middle managers in 3, 4, and 5 star hotels in Nusa Dua Region using purposive sampling method and the data analysis technique used was multiple linear regression analysis. Data collection of this research was carried out through questionnaires. Based on the results of this study, it was found that the self-esteem held by hotel management tends to be low and the environmental uncertainty faced is also low so that this will cause budgetary slack. The complexity of the tasks experienced by hotel management tends to be high so that this can also lead to budgetary slack.

Keywords: Self esteem, task complexity, environmental uncertainty, budgetary slack.
\end{abstract}

\section{PENDAHULUAN}

Hotel memiliki kegiatan operasional yang luas dan kompleks sehingga tidak memungkinkan bagi pimpinan hotel untuk memantau dan mengontrol segala kegiatan operasional hotel secara langsung.Sistem pengendalian manajemen sangat diperlukan untuk membantu pimpinan hotel dalam merencanakan serta mengontrol kegiatan operasional hotel. Alat bantu yang dapat digunakan dalam 
proses perencanaan dan pengendalian manajemen agar kegiatan bisnis dapat berjalan secara lebih efektif dan efisien adalah anggaran.Anggaran adalah rencana kegiatan selama satu periode yang tertuang secara kuantitatif (Sasongko \& Parulian, 2015). Selain itu, menurut Setiawan dan Ghozali (2016) anggaran juga dapat diartikan sebagai pernyataan tentang apa yang diharapkan, direncanakan atau diperkirakan akan terjadi dalam periode tertentu di masa depan yang dapat digunakan sebagai alat kontrol organisasi dalam jangka pendek. Penganggaran memungkinkan organisasi untuk dapat beradaptasi dengan ketidakstabilan lingkungan, membuat penggunaan sumber daya yang tersedia menjadi efisien, mengevaluasi kinerja, dan menyediakan ruang untuk saling memberikan informasi yang penting (Ajibolade \& Akinniyi, 2013).

Kontrol anggaran dapat dicapai melalui pencocokan pengeluaran aktual dengan rencana(Mah'd, Al-khadash, Idris, \& Ramadan, 2013).Anggaran sesungguhnya adalah alat akuntansi manajerial yang efektif jika terdapat keikutsertaan dari para bawahan (Thien, 2014). Pentingnya anggaran membuat peran partisipasi dari bawahan sangat diperlukan dalam proses penyusunan anggaran (anggaran partisipatif). Keikutsertaan dalam proses penyusunan anggaran merupakan suatupengambilan keputusan oleh beberapa pihak yang mempunyai dampak untukkedepannya bagi pihak yang membuat keputusan tersebut(Lubis, 2011). Melalui anggaran partisipatif, pihak-pihak yang ikut serta dalam proses penyusunan anggaran akan lebih bertanggung jawab dalam melaksanakan tugasnya untuk mencapai target yang telah ditetapkan. Selain itu anggaran partisipatif akan memberikan ruang bagi pimpinan (prinsipal) untuk 
mengetahui informasi yang dimiliki oleh bawahan. Peran serta bawahan dalam menyusun anggaran akan memberikan target anggaran yang sesuai dengan kondisi yang sesungguhnya (Arnold \& Gillenkirch, 2015).

Berdasarkan teori keagenan, hubungan kontraktual antara prinsipal dan agen menyebabkan terjadinya konflik kepentingan dikarenakan perbedaan kepentingan yang dimiliki. Perbedaan kepentingan tersebut membuat agen melakukan tindakan disfungsional agar dapat memaksimumkan kepentingan pribadinya. Tindakan disfungsional yang dapat dilakukan oleh agen dalam hal ini adalah senjangan anggaran (budgetary slack). Senjangan anggaran merupakan perbedaan laporan anggaran yang dilaporkan dengan anggaran yang tidak sesuai dengan entitas terbaik dari suatu organisasi (Puspitha \& Suardana, 2017). Pratami dan Erawati (2016)menyatakan bahwa senjangan anggaran akan muncul ketika seorang manajer dengan sengaja memerkirakan tingkat pendapatan lebih kecil (understate revenue) dan tingkat biaya lebih besar (overstate cost). Perilaku tersebut dilakukan untuk memudahkan pihak manajer dalam mencapai target yang telah ditetapkan oleh para prinsipal sehingga akan memunculkan kesan bahwa manajer memiliki kinerja yang baik sehingga target yang telah ditetapkan dapat tercapai.Selain itu, manajer akan melakukan senjangan anggaran apabila tidak adanya izin untuk ikut berpartisipasi dalam penyusunan anggaran (Yuen, Law, \& Tayles, 2015). Senjangan anggaran mengakibatkan anggaran yang dibuat oleh manajer tidak dapat mencerminkan kebutuhan organisasi yang sesungguhnya (Baerdemaeker \& Bruggeman, 2015). 
Menurut teori keagenan, senjangan anggaran juga dapat dianggap sebagai biaya yang dikenakan pada perusahaankarena membuat keputusan tentang alokasi sumber daya berdasarkan informasi yang tidak akurat dan di bawah tingkat utilitas yang diinginkan (Etemadi \& Sirghani, 2016). Teori keagenan dapat membantu dalam pengimplementasian berbagai mekanisme tata kelola untuk mengontrol tindakan agen di perusahaan(Panda \& Leepsa, 2017). Selain teori keagenan, teori atribusi juga dapat menunjukan faktor-faktor yang menyebabkan individu melakukan senjangan anggaran. Ditinjau dari teori atribusi, senjangan anggaran dapat timbul dikarenakan beberapa faktor baik dari faktor internal individu maupun eksternal individu seperti faktor self esteem, kompleksitas tugas, dan ketidakpastian lingkungan.

Faktor self esteem merupakan faktor internal individu yang berkaitan dengan penghargaan seseorang terhadap dirinya sendiri atas apa yang dimilikinya. Self esteem juga dapat didefinisikan sebagai rasa keyakinan terhadap kemampuan dan potensi yang dimiliki oleh setiap individu. Self esteem berperan penting dalam memotivasi individu agar bisa melaksanakan tugasnya sesuai dengan kemampuan diri sendiri dan memberikan keyakinan bahwa target yang ditetapkan dapat dicapai. Individu yang memiliki self esteem tinggi cenderung memandang dirinya sebagai orang yang penting dan berharga di perusahaan yang mempekerjakannya. Selain itu, individu yang memiliki self esteem yang tinggi juga akan berusaha menggunakan seluruh kemampuan yang dimilikinya untuk mencapai target yang telah ditetapkan, sehingga senjangan anggaran pun dapat dihindari(Langevin \& Mendoza, 2013). Penelitian sebelumnya yang dilakukan olehNetra dan 
Damayanthi (2017), Ardanari dan Putra (2014), Ramona (2016), serta Yasa et al (2017) menyatakan bahwa self esteem berpengaruh negatif terhadap senjangan anggaran.

Kompleksitas tugas merupakan faktor ekternal yang berkaitan dengan tugastugas yang tidak terstruktur, membingungkan, dan sulit untuk dilakukan(Yulianti, 2014). Kompleksitas tugas juga dapat didefinisikan sebagai tugas-tugas yang jumlahnya banyak dan berbeda satu dengan yang lainnya namun saling memiliki keterkaitan.Menurut Andrews dan Boyne (2014), kompleksitas tugas pada suatu perusahaan berkaitan dengan produktivitas yang tinggi.Jika kompleksitas tugas meningkat maka bawahan memerlukan keterampilan untuk menyelesaikan tugas (Garbers \& Konradt, 2014). Karena keterbatasan keterampilan yang dimiliki bawahan dan rasa tertekan yang dialami oleh bawahan sebagai akibat kompleksitas tugas maka bawahan akan menciptakan senjangan anggaran (Kahar et al., 2016). Jika para bawahan tidak menghadapi tugas yang kompleks, para bawahan tersebut akan yakin bahwa target anggaran dapat dicapai sehingga cenderung tidak menciptakan senjangan anggaran (Yeandrawita, M, \& Safitri, 2015). Beberapa peneliti sebelumnya seperti Puspitha dan Suardana (2017), Pamungkas et al (2014), serta Yeandrawita et al (2015) menemukan hasil bahwa kompleksitas tugas berpengaruh positif terhadap senjangan anggaran.

Ketidakpastian lingkungan juga merupakan faktor eksternal yang dapat memicu timbulnya senjangan anggaran. Menurut Fatmawati dan Widyaningsih (2014), faktor ketidakpastian lingkungan digunakan untuk melihat tindak lanjut dari pengimplementasian anggaran, kemampuan partisipasi individu dalam 
penyusunan anggaran, dan melihat serta mengukur kondisi dalam menciptakan penganggaran yang efektif dan efisien. Ketidakmampuan individu untuk memprediksi hal yang akan terjadi secara akurat merupakan dampak dari ketidakpastian lingkungan yang tinggi. Menurut Govindarajan (1986) dalam Wijayanthi dan Widanaputra (2016), senjangan anggaran akan berkurang ketika kondisi ketidakpastian lingkungan tinggi. Hal ini dikarenakan bawahan tidak memiliki informasi yang akurat terkait perubahan yang terjadi sehingga sulit untuk menciptakan senjangan anggaran. Ketika target anggaran dijadikan indikator untuk menilai kinerja bawahan dan bawahan lebih banyak memiliki informasi terkait kondisi lingkungan dalam suatu organisasi maka akan ada kecenderungan untuk membangun senjangan anggaran (Raudhiah, 2014). Sumber ketidakpastian lingkungan dapat berasal dari konsumen, teknologi, dan pemasok. Riset mengenai pengaruh ketidakpastian lingkungan terhadap senjangan anggaran dilakukan oleh Fatmawati dan Widyaningsih (2014) serta Wati \& Damayanthi (2017) bahwa ketidakpastian lingkungan berpengaruh negatif terhadap senjangan anggaran.

Dewasa ini, perkembangan pariwisata di Bali semakin pesat. Hal ini dapat dilihat dari meningkatnya jumlah kunjungan wisatawan yang datang ke Bali. Jumlah kunjungan wisatawan ke Bali tertuang dalam Tabel 1. 
Tabel 1.

Jumlah Kunjungan Wisatawan Ke Bali Tahun 2015 - 2017

\begin{tabular}{cc}
\hline Tahun & Jumlah Kunjungan Wisatawan \\
\hline 2015 & $4,001,835$ \\
2016 & $4,927,937$ \\
2017 & $5,697,739$ \\
\hline
\end{tabular}

Sumber: Badan Pusat Statistik Provinsi Bali, 2018

Berdasarkan Tabel 1 dapat dilihat bahwa dari tahun 2015 hingga tahun 2017 terjadi peningkatan jumlah wisatawan ke Bali yang cukup signifikan. Hal ini dikarenakan Bali memiliki daerah-daerah yang menjadi tempat destinasi pariwisata terbaik di dunia. Meningkatnya jumlah kunjungan wisatawan ke Bali membuat bisnis perhotelan di daerah-daerah yang ada di Bali semakin berkembang dan saling bersaing untuk dapat memenuhi kebutuhan setiap wisatawan. Salah satu daerah yang memiliki tingkat persaingan antar hotel yang cukup tinggi di Bali adalah Nusa Dua. Nusa Dua dikenal dengan reputasinya sebagai kawasan pariwisata terbaik ketiga di dunia menurut penilaian United Nations World Tourism Organization, sehingga membuat wisatawan semakin banyak berkunjung ke Nusa Dua setiap tahunnya. Dampak dari peningkatan jumlah kunjungan wisatawan ke Bali seharusnya mampu meningkatkan jumlah tingkat hunian kamar (room occupancy) hotel di wilayah Nusa Dua, namun hal ini berbanding terbalik dimanamenurut STR Global dalam Colliers International Indonesia(2018)tingkat hunian kamar hotel di Nusa Dua pada tahun 2017 mengalami penurunan hingga 40 persen dibandingkan tahun sebelumnya. Penurunan tingkat hunian kamar ini menunjukkan bahwa persaingan di dunia bisnis perhotelan semakin ketat sehingga antar hotel harus bersaing untuk meningkatkan pelayanannya kepada wisatawan. Hal ini juga bisa 
I Dewa Ayu Diah Nirmala Dewi dan A.A.G.P. Widanaputra. Pengaruh...

mengindikasikan bahwa terjadi penurunan kinerja manajerial yang bisa disebabkan karena penyusunan perencanaan dan pengendalian yang kurang baik oleh manajer. Penurunan kinerja tersebut bisa saja disebabkan karena penyusunan anggaran dari setiap departemen yang kurang tepat dimana target anggaran yang ditetapkan terlalu rendah dari yang seharusnya.

Sharma \& Agarwala (2013) menyatakan bahwa self esteem merupakan kepercayaan diri yang dimiliki seseorang, kepuasan terhadap suatu hal dan rasa menghormati diri sendiri. Self esteem bisa terbentuk dari kondisi yang dialami oleh masing-masing individu serta cara orang lain memperlakukan individu tersebut. Jika seseorang merasa bahwa dirinya berharga, penting dan berpengaruh maka akan timbul rasa kepercayaan diri dalam melaksanakan setiap tugasnya dan mampu menciptakan hasil yang optimal.

Ada dua tipe self esteem, yakni self esteem tinggi dan self esteem rendah. Individu yang memiliki self esteem tinggi cenderung mudah membina hubungan kerja sama dengan orang lain, memiliki rasa optimis, dan menjadikan dirinya sebagai orang yang berhasil. Jika individu memiliki self esteem yang rendah maka cenderung lebih cepat pesimis serta merasa bahwa dirinya tidak akan mampu menyelesaikan tugasnya dengan baik. Semakin rendah self esteem yang dimiliki oleh individu maka individu tersebut cenderung akan melakukan senjangan anggaran karena ketidakpercayaan individu dengan kemampuan yang dimilikinya dalam mencapai target yang ditetapkan. Hal ini sejalan dengan temuan penelitian yang dilakukan oleh Pamungkas et al (2014), Netra dan Damayanthi (2017), Ramona (2016), serta Yasa et al (2017)yang menyatakan bahwa self esteem 
berpengaruh negatif terhadap senjangan anggaran. Berdasarkan uraian diatas, maka hipotesis yang diajukan dalam penelitian ini adalah sebagai berikut:

$\mathrm{H}_{1}$ : Semakin rendahself esteem individu, maka semakin tinggi tingkat senjangan anggaran.

Kompleksitas tugas merupakan tugas yang diberikan oleh atasan kepada bawahan yang tidak terstruktur dan terkadang membuat bingung para bawahan. Tugas yang kompleks dapat memicu timbulnya senjangan anggaran. MenurutPuspitha \& Suardana (2017), individu yang mengalami kompleksitas tugas dan berpartisipasi dalam penyusunan anggaran akan cenderung menciptakan senjangan anggaran. Hal ini didasari oleh keinginan individu untuk dapat mencapai target dengan mudah dan menunjukkan bahwa kinerja individu tersebut sangat baik. Sebaliknya, jika individu tidak mendapatkan tugas yang kompleks maka kecenderungan untuk melakukan senjangan anggaran akan berkurang.

Penelitian yang dilakukan oleh Puspitha dan Suardana (2017), Pamungkas et al (2014), Yeandrawita et al (2015) menemukan bahwa kompleksitas tugas berpengaruh positif terhadap senjangan anggaran. Berdasarkan uraian diatas, maka hipotesis yang diajukan dalam penelitian ini adalah sebagai berikut:

$\mathrm{H}_{2}$ : Semakin tinggi tingkat kompleksitas tugas, maka semakin tinggi tingkat senjangan anggaran.

Kondisi organisasi yang berkaitan dengan lingkungan selalu mengalami perubahan yang membuat perusahaan relatif sering melakukan perubahan. Adanya ketidakpastian lingkungan membuat para manajer sulit untuk memprediksi sesuatu yang terjadi di lingkungannya secara tepat. Dalam industri perhotelan,perubahan teknologi, konsumen dan pemasok merupakan salah satu 
komponen ketidakpastian lingkungan yang cukup sulit untuk diprediksi. Apabila ketidakpastian yang dialami industri perhotelan relatif rendah, maka akan memudahkan manajer untuk memprediksi keadaan sehingga dapat diambil langkah-langkah yang tepat untuk mengatasi perubahan lingkungan.

Selain itu, ketidakpastian lingkungan yang rendah akan membuat manajer melakukan senjangan anggaran. Hal ini dikarenakan manajer memanfaatkan informasi yang dimilikinya untuk menciptakan senjangan anggaran. Sebaliknya, apabila ketidakpastian lingkungan yang dialami oleh industri perhotelan tersebut tinggi, maka manajer tidak akan mampu mengambil langkah yang tepat dalam ketidakstabilan lingkungan yang terjadi dan akan sulit untuk menciptakan senjangan anggaran. Penelitian yang dilakukan oleh Fatmawati dan Widyaningsih (2014) serta Wati \& Damayanthi (2017) menemukan bahwa ketidakpastian lingkungan berpengaruh negatif terhadap senjangan anggaran. Berdasarkan uraian diatas, maka hipotesis yang diajukan dalam penelitian ini adalah sebagai berikut:

$\mathrm{H}_{3}$ : Semakin rendah ketidakpastian lingkungan yang terjadi, maka semakin tinggi tingkat senjangan anggaran.

\section{METODE PENELITIAN}

Wilayah Nusa Dua memiliki 32 hotel berbintang yang terdiri dari hotel bintang 2, 3, 4, dan 5. Penelitian ini dilakukan pada hotel bintang 3, 4, dan 5 karena hotel berklasifikasi tersebut akan melibatkan manajer tingkat menengahdalam penyusunan anggaran dengan metode bottom-up. Alasan peneliti memilih wilayah Nusa Dua sebagai lokasi penelitian karena kawasan tersebut memiliki reputasi sebagai kawasan pariwisata terbaik ketiga di dunia dan berkelas internasional 
menurut United Nations World Tourism Organization dan memiliki perkembangan pariwisata yang cukup pesat sehingga membuat persaingan pada industri perhotelan semakin ketat. Persaingan industri perhotelan yang semakin kompetitif di Wilayah Nusa Dua membuat para manajer hotel berupaya menyusun anggaran yang tepat agar dapat mencerminkan kinerja yang baik.

Populasi dalam penelitian ini adalah seluruh manajer hotel bintang 3, 4, dan 5 di Wilayah Nusa Dua. Sampel dalam penelitian ini sebanyak 234 manajer tingkat menengah pada hotel bintang 3, 4, dan 5 di Wilayah Nusa Dua.Metode penentuan sampel yang digunakan dalam penelitian ini adalah metode purposive sampling.

Penelitian ini menggunakan analisis regresi linear berganda untuk menguji pengaruh antara variabel bebas terhadap variabel terikat, yaitu pengaruh self esteem, kompleksitas tugasdan ketidakpastian lingkungan terhadap senjangan anggaran. Data yang diperoleh kemudian diolah dengan menggunakan program SPPS. Hasil analisis dinyatakan dalam model persamaan analisis regresi linear berganda sebagai berikut:

$$
Y=\alpha+\beta_{1} X_{1}+\beta_{2} X_{2}+\beta_{3} X_{3}+e
$$

Keterangan:

$\mathrm{Y} \quad=$ Senjangan anggaran

$\alpha \quad=$ Konstanta

$\mathrm{X}_{1} \quad=$ Self esteem

$\mathrm{X}_{2} \quad=$ Kompleksitas tugas

$\mathrm{X}_{3} \quad=$ Ketidakpastian lingkungan

$\beta_{1} \quad=$ Koefisien regresi self esteem

$\beta_{2} \quad=$ Koefisien regresi kompleksitas tugas

$\beta_{3} \quad=$ Koefisien regresi ketidakpastian lingkungan

e $\quad=$ Error (variabel pengganggu) 


\section{HASIL DAN PEMBAHASAN}

Penelitian ini dilakukan pada 26 hotel bintang 3, 4, dan 5 di Wilayah Nusa Dua. Data penelitian ini dikumpulkan melalui penyebaran kuesioner yang dikirim langsung oleh peneliti. Peneliti menyebarkan kuesioner sebanyak 234 eksemplar dimana setiap hotel dibagikan sebanyak 9 kuesioner yang ditujukan untuk General Manager dan seluruh kepala departemen yang ikut serta dalam penyusunan anggaran hotel serta telah menduduki jabatannya minimal selama 1 tahun. Kuesioner diambil kembali dalam kurun waktu 14 hari dan kuesioner yang kembali sebanyak 177 dari 234 kuesioner yang telah disebar. Hal ini dikarenakan adanya peraturan khusus dari pihak hotel dan kesibukan dari responden. Rincian pengiriman dan pengembalian kuesioner disajikan dalam Tabel 2.

Tabel 2.

Rincian Pengiriman dan Pengembalian Kuesioner

\begin{tabular}{|c|c|}
\hline Keterangan & Jumlah \\
\hline Kuesioner yang disebar & 234 \\
\hline Kuesioner yang tidak kembali & $(57)$ \\
\hline Kuesioner yang kembali & 177 \\
\hline Kuesioner yang dianalisis & 177 \\
\hline Tingkat pengembalian (response rate) & \\
\hline Kuesioner yang kembali x $100 \%$ & $75 \%$ \\
\hline Kuesioner yang disebar & \\
\hline Tingkat pengembalian yang digunakan (useable response rate) & $75 \%$ \\
\hline
\end{tabular}
Sumber: Data diolah, 2018

Tabel 2 menunjukkan bahwa dari 234 kuesioner yang disebar kepada responden sebanyak 177 kuesioner yang kembali dan 57 kuesioner yang tidak kembali. Kuesioner yang kembali telah diisi secara lengkap oleh responden dan telah memenuhi ketentuan sehingga tidak ada kuesioner yang gugur. 
Karakteristik responden berkaitan dengan profil dari setiap responden yang telah mengisi kuesioner penelitian ini. Karakteristik responden dalam penelitian ini meliputi usia, pendidikan terakhir, jabatan dari responden, dan lama bekerja di hotel tersebut. Karakteristik demografi responden dari penelitian ini disajikan pada Tabel 3.

Tabel 3.

Karakteristik Responden

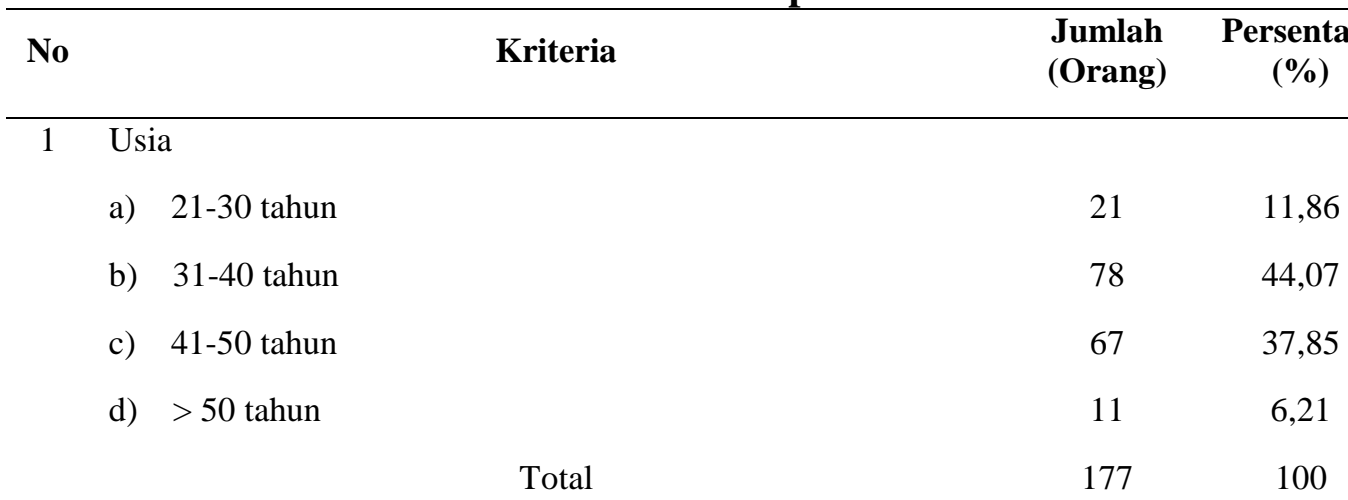

2 Pendidikan Terakhir
a) $\mathrm{S} 2$
10
5,65
b) $\mathrm{S} 1$
62
35,03
c) D3
35
19,77
d) Lainnya

$70 \quad 39,55$
Total
177
100

3 Jabatan
a) General Manager
13
7,34
b) Human Resource Manager (HRD Department Head)
23
12,99
c) Front Office Manager (Front Office Department
Head)
20
11,30
d) Sales \& Marketing Director (Sales \& Marketing
Department Head)
16
9,04
e) Food \& Beverage Manager $(F \& B$ Service
Department Head)
21
11,86
f) Executive Chef ( $F \& B$ Kitchen Department Head)
21
11,86 
g) Executive Housekeeper (Housekeeping Department Head) 23

h) Accounting Manager (Accounting Department Head) $18 \quad 17$

i) Chief Engineering (Engineering Department Head) $\quad 22 \quad 12,43$

$\begin{array}{lll}\text { Total } & 177 & 100\end{array}$

4 Lama Bekerja

a) 1-5 tahun $\quad 100 \quad 56,50$

b) 6-10 tahun $\quad 48 \quad 27,12$

$\begin{array}{lll}\text { c) }>10 \text { tahun } & 29 & 16,38\end{array}$

Total $177 \quad 100$

Sumber: Data diolah, 2018

Karakteristik usia digunakan untuk mengetahui rentang usia dari setiap responden yang bekerja di hotel bintang 3, 4, dan 5 di Wilayah Nusa Dua. Berdasarkan tabel tersebut, diketahui responden yang berusia 21 tahun hingga 30 tahun berjumlah 21 orang $(11,86 \%)$, responden dengan rentang usia 31 tahun hingga 40 tahun berjumlah 78 orang $(44,07 \%)$, responden dengan rentang usia 41 tahun hingga 50 tahun berjumlah 67 orang $(37,85 \%)$, dan responden yang berusia lebih dari 50 tahun berjumlah 11 orang $(6,21 \%)$.

Karakteristik pendidikan terakhir responden digunakan untuk mengetahui pola pikir dan tingkat intelektualitas yang dimiliki oleh responden. Responden dengan pendidikan terakhir S2 sebanyak 10 orang $(5,65 \%)$, responden dengan pendidikan terakhir S1 sebanyak 62 orang responden (35,03\%), responden dengan pendidikan terakhir D3 sebanyak 35 orang (19,77\%), dan sebanyak 70 orang $(39,55 \%)$ dengan pendidikan terakhir selain kriteria yang ada pada tabel.

Karakteristik jabatan menggambarkan posisi atau kedudukan responden pada hotel tersebut. Responden yang memiliki jabatan sebagai General Manager sebanyak 13 orang (7,34\%), Human Resource Manager sebanyak 23 orang 
(12,99\%), Front Office Manager sebanyak 20 orang (11,30\%), Sales \& Marketing Director sebanyak 16 orang (9,04\%), Food \& Beverage Manager sebanyak 21 orang (11,86\%), Executive Chef sebanyak 21 orang (11,86\%), Executive Housekeeper sebanyak 23 orang (12,99\%), Accounting Manager sebanyak 18 orang (10,17\%), dan Chief Engineering sebanyak 22 orang $(12,43 \%)$.

Kriteria lama bekerja digunakan untuk melihat responden yang mengisi kuesioner sudah memenuhi kriteria sampel yakni telah menduduki jabatan sebagai manajer tingkat menengah minimal selama 1 tahun di hotel tersebut. berdasarkan Tabel 4.2, responden yang bekerja selama 1-5 tahun sebanyak 100 orang (56,50\%), responden yang bekerja selama 6-10 tahun sebanyak 48 orang $(27,12 \%)$, dan responden yang bekerja selama lebih dari 10 tahun sebanyak 29 orang $(16,38 \%)$.

Statistik deskriptif mendeskripsikan informasi mengenai karakteristik masing-masing variabel penelitian yang terdiri dari nilai minimum, nilai maksimum, rata-rata (mean), dan standar deviasi. Hasil analisis statistik deskriptif disajikan dalam Tabel 4.

Tabel 4.

Hasil Analisis Statistik Deskriptif

\begin{tabular}{lccccc}
\hline \multicolumn{1}{c}{ Variabel } & N & Min & Maks & $\begin{array}{c}\text { Rata- } \\
\text { Rata }\end{array}$ & $\begin{array}{c}\text { Standar } \\
\text { Deviasi }\end{array}$ \\
\hline Self Esteem $\left(\mathrm{X}_{1}\right)$ & 177 & 10,00 & 20,00 & 14,2429 & 3,42497 \\
Kompleksitas Tugas $\left(\mathrm{X}_{2}\right)$ & 177 & 12,00 & 24,00 & 18,1469 & 3,39467 \\
Ketidakpastian Lingkungan $\left(\mathrm{X}_{3}\right)$ & 177 & 13,00 & 32,00 & 22,2881 & 5,74570 \\
Senjangan Anggaran $(\mathrm{Y})$ & 177 & 14,00 & 23,00 & 19,6102 & 2,11878 \\
\hline Sumber: Data diolah, 2018 & & & & &
\end{tabular}

Berdasarkan Tabel 4 dapat dilihat bahwa jumlah pengamatan $(\mathrm{N})$ dalam penelitian ini adalah sebanyak 177 . Variabel self esteem $\left(\mathrm{X}_{1}\right)$ memiliki nilai minimum sebesar 10 , nilai maksimum sebesar 20 , dan nilai rata-rata sebesar 
14,2429. Hal ini menandakan bahwa responden dalam penelitian ini cenderung memiliki self esteem yang rendah. Nilai standar deviasi untuk variabel self esteem sebesar 3,42497, yang artinya standar penyimpangan data terhadap nilai rataratanya adalah sebesar 3,42497 .

Variabel kompleksitas tugas $\left(\mathrm{X}_{2}\right)$ memiliki nilai minimum sebesar 12, nilai maksimum sebesar 24, dan nilai rata-ratanya sebesar 18,1469 yang artinya bahwa responden dalam penelitian ini cenderung mengalami kompleksitas tugas yang tinggi. Standar penyimpangan data terhadap nilai rata-rata untuk variabel kompleksitas tugas sebesar 3,39467. Variabel ketidakpastian lingkungan $\left(\mathrm{X}_{3}\right)$ memiliki nilai maksimum sebesar 32 , nilai minimun sebesar 13 , dan nilai rata-rata sebesar 22,2881. Hal ini menunjukkan bahwa responden cenderung menghadapi ketidakpastian lingkungan yang rendah. Nilai standar deviasi untuk variabel ketidakpastian lingkungan sebesar 5,74570, yang artinya standar penyimpangan data terhadap nilai rata-ratanya adalah sebesar 5,74570. Variabel senjangan anggaran (Y) memiliki nilai maksimum sebesar 23, nilai minimum sebesar 14 , dan nilai rata-rata sebesar 19,6102. Hal ini menunjukkan tingginya kecenderung responden dalam melakukan senjangan anggaran. Standar penyimpangan data terhadap nilai rata-rata untuk variabel senjangan anggaran sebesar 2,11878.

Penelitian ini menggunakan analisis regresi berganda untuk menguji pengaruh antara variabel bebas terhadap variabel terikat, yaitu pengaruh self esteem, kompleksitas tugasdan ketidakpastian lingkungan terhadap senjangan anggaran. Adapun model persamaan analisis regresi linear berganda yang digunakan adalah sebagai berikut: 
Hasil dari uji regresi linear berganda dapat dilihat pada Tabel 5.

Tabel 5.

Hasil Uji Regresi Linear Berganda

\begin{tabular}{lccc}
\hline \multicolumn{1}{c}{ Variabel } & $\begin{array}{c}\text { Koefisien } \\
\text { Regresi }\end{array}$ & t-hitung & Signifikansi \\
\hline Konstanta & 19,992 & 58,648 & 0,000 \\
Self Esteem $\left(\mathrm{X}_{1}\right)$ & $-0,182$ & $-14,408$ & 0,000 \\
Kompleksitas Tugas $\left(\mathrm{X}_{2}\right)$ & 0,388 & 30,811 & 0,000 \\
Ketidakpastian Lingkungan $\left(\mathrm{X}_{3}\right)$ & $-0,211$ & $-25,311$ & 0,000 \\
$R$ Square & $:$ & 0,930 & \\
Adjusted $R$ Square $:$ & 0,929 & \\
F-hitung & $:$ & 766,340 & \\
Signifikansi F $\quad:$ & 0,000 & \\
\hline \multicolumn{2}{l}{ Sumber: Data diolah, 2018 }
\end{tabular}

Sumber: Data diolah, 2018

Berdasarkan Tabel 5 dapat dilihat bahwa nilai konstanta $(\alpha)$ sebesar 19,992, nilai koefisien regresi $\left(\beta_{1}\right)$ sebesar $-0,182$, nilai koefisien regresi $\left(\beta_{2}\right)$ sebesar 0,388 , serta nilai koefisien regresi $\left(\beta_{3}\right)$ sebesar $-0,211$. Berdasarkan hasil uji regresi linear berganda, maka model persamaan regresi linear berganda dalam penelitian ini akan tampak sebagai berikut:

$\mathrm{Y}=19,992-0,182 \mathrm{X}_{1}+0,388 \mathrm{X}_{2}-0,211 \mathrm{X}_{3}+\mathrm{e}$

Nilai konstanta sebesar 19,992 memiliki arti apabila self esteem $\left(\mathrm{X}_{1}\right)$, kompleksitas tugas $\left(\mathrm{X}_{2}\right)$, dan ketidakpastian lingkungan $\left(\mathrm{X}_{3}\right)$ sama dengan nol, maka nilai senjangan anggaran (Y) sebesar 19,992 satuan.

Nilai koefisien regresi self esteem $\left(\mathrm{X}_{1}\right)$ sebesar -0,182, memiliki arti bahwa apabila self esteem $\left(\mathrm{X}_{1}\right)$ naik sebesar satu satuan sementara kompleksitas tugas $\left(\mathrm{X}_{2}\right)$ dan ketidakpastian lingkungan $\left(\mathrm{X}_{3}\right)$ diasumsikan konstan, maka senjangan anggaran (Y) akan menurun sebesar 0,182.

Nilai koefisien regresi kompleksitas tugas $\left(\mathrm{X}_{2}\right)$ sebesar 0,388, memiliki arti bahwa apabila kompleksitas tugas $\left(\mathrm{X}_{2}\right)$ naik sebesar satu satuan serta self esteem 
$\left(\mathrm{X}_{1}\right)$ dan ketidakpastian lingkungan $\left(\mathrm{X}_{3}\right)$ diasumsikan konstan, maka senjangan $\operatorname{anggaran}(\mathrm{Y})$ akan meningkat sebesar 0,388.

Nilai koefisien regresi ketidakpastian lingkungan $\left(X_{3}\right)$ sebesar -0,211, memiliki arti apabila ketidakpastian lingkungan $\left(\mathrm{X}_{3}\right)$ naik satu satuan sedangkan self esteem $\left(\mathrm{X}_{1}\right)$ dan kompleksitas tugas $\left(\mathrm{X}_{2}\right)$ diasumsikan konstan maka senjangan anggaran (Y) akan menurun sebesar 0,211.

Berdasarkan Tabel 5, dapat dilihat bahwa nilai adjusted $R^{2}$ sebesar 0,929. Hal ini menunjukkan bahwa sebesar 92,9\% variasi variabel senjangan anggaran (Y) mampu dijelaskan oleh variabel self esteem $\left(\mathrm{X}_{1}\right)$, kompleksitas tugas $\left(\mathrm{X}_{2}\right)$ dan ketidakpastian lingkungan $\left(\mathrm{X}_{3}\right)$, sedangkan sisanya sebesar $7,1 \%$ dipengaruhi oleh variabel lain yang tidak dimasukkan dalam model penelitian ini.

Berdasarkan Tabel 5, dapat diketahui bahwa $\mathrm{F}$ memiliki nilai sebesar 766,340 dengan tingkat signifikansi sebesar 0,000. Tingkat signifikansi F sebesar 0,000 lebih kecil dibandingkan tingkat signifikansi $(\alpha)$ sebesar 0,05 , yang artinya bahwa seluruh variabel mampu menjelaskan fenomena senjangan anggaran pada hotel berbintang di Wilayah Nusa Dua dan model regresi dalam penelitian ini layak untuk digunakan.

Pada Tabel 5 menunjukkan nilai koefisien regresi untuk variabel self esteem sebesar $-0,182$ dan nilai signifikansi sebesar 0,000 lebih kecil dibandingkan tingkat signifikansi $(\alpha)$ sebesar 0,05 yang berarti bahwa hipotesis diterima. Hal ini menunjukkan bahwa self esteem berpengaruh negatif pada senjangan anggaran.

Berdasarkan Tabel 5 dapat diketahui nilai koefisien regresi untuk variabel kompleksitas tugas sebesar 0,388 dan nilai signifikansi sebesar 0,000 lebih kecil 
dibandingkan tingkat signifikansi $(\alpha)$ sebesar 0,05 yang berarti bahwa hipotesis diterima. Hal ini menunjukkan bahwa kompleksitas tugas berpengaruh positif pada senjangan anggaran.

Berdasarkan Tabel 5 dapat diketahui nilai koefisien regresi untuk variabel ketidakpastian lingkungan sebesar $-0,211$ dan nilai signifikansi sebesar 0,000 lebih kecil dibandingkan tingkat signifikansi $(\alpha)$ sebesar 0,05 yang berarti bahwa hipotesis diterima. Hal ini menunjukkan bahwa ketidakpastian lingkungan berpengaruh negatif pada senjangan anggaran.

Berdasarkan hasil uji t, hipotesis 1 yang menyatakan bahwa semakin rendahself esteem individu, maka semakin tinggi tingkat senjangan anggaran dapat diterima. Hal ini ditunjukkan dengan nilai koefisien regresi untuk variabel self esteem sebesar -0,182 dan nilai signifikansi sebesar 0,000 lebih kecil dibandingkan tingkat signifikansi $(\alpha)$ sebesar 0,05 . Berdasarkan hal tersebut dapat disimpulkan bahwa semakin rendah self esteem yang dimiliki oleh manajer maka semakin tinggi tingkat senjangan anggaran di hotel berbintang Wilayah Nusa Dua. Hal ini berarti ketika manajer memiliki self esteem yang rendah pada proses penyusunan anggaran, maka kecenderungan untuk melakukan senjangan anggaran akan semakin tinggi.

Self esteem yang rendah dapat disebabkan karena manajer kurang percaya terhadap kemampuan yang mereka miliki untuk mencapai target yang telah ditetapkan atau bahkan ragu-ragu dalam mengambil suatu tindakan terkait dengan pekerjaan yang harus dilakukannya. Manajer dengan self esteem yang rendah cenderung merasa bahwa manajer tersebut tidak memiliki sesuatu yang bisa 
dibanggakan. Hasil penelitian ini sejalan dengan hasil penelitian yang dilakukan oleh Pamungkas et al (2014), Netra dan Damayanthi (2017), Ramona (2016), serta Yasa et al (2017)yang menyatakan bahwa rendahnya self esteem yang dimiliki seseorang cenderung akan meningkatkan senjangan anggaran.

Berdasarkan hasil uji t, hipotesis 2 dapat diterima dimana hipotesis 2 menyatakan bahwa semakin tinggi tingkat kompleksitas tugas, maka semakin tinggi tingkat senjangan anggaran. Hal ini ditunjukkan dengan nilai koefisien regresi untuk variabel kompleksitas tugas sebesar 0,388 dan nilai signifikansi sebesar 0,000 lebih kecil dibandingkan tingkat signifikansi $(\alpha)$ sebesar 0,05. Berdasarkan hal tersebut dapat disimpulkan bahwa semakin tinggi kompleksitas tugas yang dialami manajer maka semakin tinggi pula tingkat senjangan anggaran di hotel berbintang Wilayah Nusa Dua. Hal ini didasari oleh keinginan manajer untuk dapat mencapai target dengan mudah.

Hotel memiliki kegiatan operasional yang luas dan kompleks sehingga manajer yang bekerja di hotel dihadapkan dengan tugas-tugas yang banyak dan kompleks. Tugas-tugas yang bersifat kompleks tersebut cenderung membuat manajer bingung dalam menentukan tugas mana yang harus diprioritaskan atau dikerjakan terlebih dahulu. Hal tersebut membuat manajer merasa tertekan untuk mencapai target yang telah ditetapkan sehingga manajer akan cenderung melakukan senjangan anggaran dimana dengan melakukan senjangan anggaran akan membantu manajer tersebut dapat dengan mudah mencapai target dan juga kinerjanya dapat dilihat baik. Hasil penelitian ini sejalan dengan penelitian yang dilakukan oleh Puspitha dan Suardana (2017), Pamungkas et al (2014), 
Yeandrawita et al (2015) yang menyatakan bahwa kompleksitas tugas yang tinggi cenderung akan meningkatkan senjangan anggaran.

Berdasarkan hasil uji t, hipotesis 3dapat diterima dimana hipotesis 3 menyatakan bahwa semakin rendah tingkat ketidakpastian lingkungan, maka semakin tinggi tingkat senjangan anggaran. Hal ini ditunjukkan dengan nilai koefisien regresi untuk variabel ketidakpastian lingkungan sebesar -0,211 dan nilai signifikansi sebesar 0,000 lebih kecil dibandingkan tingkat signifikansi $(\alpha)$ sebesar 0,05. Berdasarkan hal tersebut dapat disimpulkan bahwa semakin rendah ketidakpastian lingkungan yang dihadapi oleh manajer, maka semakin tinggi kecenderungan manajer dalam melakukan senjangan anggaran di hotel berbintang Wilayah Nusa Dua. Hal ini dikarenakan manajer tidak mengalami kesulitan dalam memperoleh informasi-informasi yang dibutuhkan sehingga dalam menyelesaikan pekerjaan sesuai dengan target anggaran, manajer dapat dengan mudah menentukan tindakan yang harus dilakukannya.

Ketidakpastian lingkungan yang rendah dapat memicu terjadinya senjangan anggaran, dikarenakan manajer memiliki seluruh informasi teknis terkait ranah tanggung jawabnya yang dapat digunakan untuk memprediksi kondisi lingkungan. Seluruh informasi yang dimiliki oleh manajer tersebut akan disimpan dan manajer akan memberikan informasi yang bias kepada atasan sehingga atasan tidak memilikiinformasi yang cukup untuk memprediksi kondisi lingkungan. Selain itu, dengan berkembangnya teknologi informasi dewasa ini membuat manajer hotel dapat dengan mudah mengakses data-data yang diperlukan sehingga segala aktivitas dapat dikendalikan. Hasil penelitian ini sejalan dengan penelitian yang 
dilakukan oleh Fatmawati dan Widyaningsih (2014) serta Wati \& Damayanthi (2017) yang menyatakan bahwa kondisi lingkungan yang stabil (ketidakpastian lingkungan yang rendah), maka akan cenderung meningkatkan senjangan anggaran.

Penelitian ini dapat memberikan kontribusi guna menambah pengetahuan mengenai pengaruh self esteem, kompleksitas tugas, dan ketidakpastian lingkungan pada senjangan anggaran di hotel berbintang Wilayah Nusa Dua. Hasil uji dalam penelitian ini ditemukan bahwa variabel self esteem dan ketidakpastian lingkungan berpengaruh negatif pada senjangan anggaran serta variabel kompleksitas tugas berpengaruh positif pada senjangan anggaran.

Dalam teori keagenan (agency theory) diasumsikan bahwa masing-masing individu baik dari pihak atasan (prinsipal) maupun manajer (agen) memiliki kepentingan yang berbeda. Perbedaan kepentingan antara atasan dan manajer dalam proses penyusunan anggaran akan menimbulkan konflik kepentingan (agency conflict). Adanya konflik kepentingan tersebut akan memicu terjadinya senjangan anggaran dikarenakan manajer cenderung melakukan moral hazard demi memaksimumkan kepentingan pribadinya yang bertentangan dengan keinginan atasan. Manajer yang melakukan senjangan anggaran cenderung dipengaruhi oleh faktor internal maupun eksternal. Hal ini sejalan dengan teori atribusi yang mengasumsikan bahwa faktor internal dan eksternal dari individu mampu mempengaruhi perilakunya dan mempengaruhi individu dalam menyikapi suatu keadaan. Individu yang melakukan senjangan anggaran cenderung dipengaruhi oleh faktor internal seperti salah satunya adalah masalah self esteem 
dan faktor eksternal seperti kompleksitas tugas yang dialami individu serta adanya ketidakpastian lingkungan.

Self esteem berpengaruh negatif pada senjangan anggaran, dimana semakin rendah self esteem yang dimiliki oleh individu maka kecenderungan untuk melakukan senjangan anggaran menjadi tinggi. Self esteem yang rendah akan membuat individu cenderung pesimis dan tidak percaya bahwa dirinya mampu untuk menyelesaikan target yang telah ditetapkan. Jika self esteem dari individu dibiarkan rendah maka hal ini akan berdampak pada kinerja individu serta kinerja perusahaan kedepannya. Target akan dapat tercapai jika individu memiliki self esteem yang tinggi. Self esteem yang tinggi akan menumbuhkan rasa optimis dalam diri individu untuk mencapai target sehingga dapat mencerminkan kinerja yang sesungguhnya.

Berdasarkan penelitian ini, ditemukan bahwa kompleksitas tugas berpengaruh positif pada senjangan anggaran. Hal ini berarti bahwa semakin tinggi tingkat kompleksitas tugas yang dialami individu maka semakin tinggi pula potensi senjangan anggaran akan terjadi. Tugas-tugas yang cukup kompleks di sektor private khususnya di bidang perhotelan membuat individu merasa tertekan dalam bekerja. Individu yang mengalami kompleksitas tugas yang tinggi dan berpartisipasi dalam proses penyusunan anggaran cenderung akan melakukan senjangan anggaran. Hal ini didasari atas keinginan individu yang ingin dengan mudah dapat mencapai target dan ingin agar kinerjanya dapat terlihat baik oleh atasan (prinsipal). 
Dalam penelitian ini, ketidakpastian lingkungan berpengaruh negatif pada senjangan anggaran. Hal ini berarti bahwa semakin rendah tingkat ketidakpastian lingkungan, maka semakin tinggi tingkat senjangan anggaran. Atasan (prinsipal) cenderung membuat target anggaran yang terlalu ketat sehingga hal ini akan mendorong manajer (agen) untuk melindungi dirinya dan posisinya dari ketidaktercapaian target anggaran yang telah dibuat. Ketika kondisi lingkungan relatif stabil atau dengan kata lain ketidakpastian lingkungan di industri perhotelan rendah maka hal ini akan memudahkan manajer (agen) memperoleh informasi yang dapat digunakan untuk memprediksi keadaan dan perubahan yang terjadi, sehingga dapat direncanakan tindakan-tindakan yang harus dilakukan untuk mengatasi keadaan dan perubahan yang terjadi. Manajer (agen) yang memiliki informasi yang lebih banyak cenderung akan memberikan informasi yang bias kepada atasan (prinsipal). Hal ini dikarenakan keterbatasan informasi yang dimiliki oleh atasan (prinsipal) untuk memprediksi kondisi lingkungannya sehingga akan mendorong manajer (agen) untuk melakukan senjangan anggaran demi tercapainya target anggaran.

Penelitian ini dapat digunakan sebagai bahan pertimbangan bagi pihak hotel berbintang di Wilayah Nusa Dua agar dapat menyusun anggaran yang efektif, efisien, dan sesuai dengan kinerja sesungguhnya sehingga dapat meminimalisir terjadinya senjangan anggaran. Terkait self esteem manajer (agen) yang rendah perlu mendapat perhatian lebih agar manajer (agen) yang ikut serta dalam proses penyusunan anggaran dapat mencapai target anggaran dengan rasa optimis dan memiliki rasa percaya terhadap kemampuan terbaik yang dimiliki. Selain itu, 
atasan (prinsipal) juga perlu menyesuaikan tugas-tugas yang diberikan kepada manajer (agen) sesuai dengan kemampuannya agar tidak terjadi kompleksitas tugas yang tinggi dimana akan berpengaruh terhadap kinerjanya dalam mencapai target. Pihak hotel juga perlu melakukan pertimbangan lebih baik lagi terkait target anggaran yang harus dicapai agar mencerminkan anggaran yang realistis karena ketika manajer (agen) memiliki seluruh informasi yang dapat digunakan sebagai bahan untuk memprediksi kondisi lingkungan, maka manajer (agen) cenderung akan melakukan senjangan anggaran melalui proses partisipasi.

\section{SIMPULAN}

Hasil penelitian ini menunjukkan bahwa self esteem berpengaruh negatif pada senjangan anggaran. Hal ini berarti semakin rendah self esteem yang dimiliki oleh individu maka semakin tinggi tingkat senjangan anggaran. Manajer yang memiliki self esteem yang rendah akan cenderung pesimis dan merasa bahwa target anggaran yang ditetapkan tidak bisa dicapai dengan kemampuan yang dimiliki sehingga manajer akan cenderung melakukan senjangan anggaran untuk dapat mencapai target.

Hasil dari penelitian ini menunjukkan bahwa kompleksitas tugas berpengaruh positif pada senjangan anggaran, yang berarti bahwa semakin tinggi tingkat kompleksitas tugas yang dialami oleh individu maka semakin tinggi pula tingkat senjangan anggaran. Hal ini dikarenakan manajer yang mengalami tingkat kompleksitas tugas yang tinggi tidak mengetahui dengan pasti tugas yang diterima serta mengalami kesulitan saat menyelesaikan tugas-tugasnya, sehingga manajer 
I Dewa Ayu Diah Nirmala Dewi dan A.A.G.P. Widanaputra. Pengaruh...

akan melakukan senjangan anggaran agar dapat terlihat bahwa seluruh tugas-tugas yang diberikan dapat diselesaikan dengan baik.

Hasil penelitian ini juga menunjukkan bahwa ketidakpastian lingkungan berpengaruh negatif pada senjangan anggaran, yang berarti bahwa semakin rendah ketidakpastian lingkungan maka semakin tinggi tingkat senjangan anggaran. Hal ini disebabkan ketika manajer menghadapi ketidakpastian lingkungan yang rendah dalam proses penyusunan anggaran maka manajer tidak akan kesulitan dalam memiliki seluruh informasi yang dapat digunakan untuk memprediksi perubahanperubahan yang terjadi, sehingga akan mendorong manajer untuk melakukan senjangan anggaran.

Bagi manajer puncak hotel berbintang di Wilayah Nusa Dua sebaiknya perlu memperhatikan kembali proses penyusunan anggaran dan juga batasan anggaran setiap departemen agar dapat mencerminkan kebutuhan dari departemen tersebut. Selain itu, manajer puncak sebaiknya menyesuaikan tugas-tugas yang diberikan kepada bawahan sesuai dengan kemampuannya sehingga dapat meminimalisir terjadinya senjangan anggaran.

Bagi jajaran manajer tingkat menengah hotel berbintang di Wilayah Nusa Dua yang berpartisipasi dalam proses penyusunan anggaran hendaknya dapat meningkatkan self esteem yang dimiliki, karena self esteem ini penting untuk menumbuhkan rasa percaya diri atas kemampuan yang dimiliki dalam mencapai target sehingga anggaran yang disusun akan mencerminkan kebutuhan sesungguhnya dari masing-masing departemen. 
Sampel yang digunakan dalam penelitian ini hanya terbatas pada hotel berbintang di Wilayah Nusa Dua, sehingga bagi peneliti selanjutnya dapat melakukan penelitian pada perusahaan sejenis dan di lokasi yang berbeda atau melakukan penelitian di perusahaan yang berbeda seperti koperasi, bank, lembaga perkreditan desa, perusahaan manufaktur. Selain itu, peneliti selanjutnya juga dapat mempertimbangkan faktor-faktor lain seperti insentif, budget monitoring, kapasitas individu, atau reputasi yang dapat mempengaruhi senjangan anggaran.

\section{REFERENSI}

Ajibolade, S. O., \& Akinniyi, O. K. (2013). The Influence Of Organisational Culture And Budgetary Participation On Propensity To Create Budgetary Slack In Public Sector Organisations. British Journal Of Arts And Social Sciences, 13(I), 69-83.

Andrews, R., \& Boyne, G. A. (2014). Task Complexity, Organization Size And Administrative Intensity: The Case Of Uk Universities. Public Administration, 92(3), 656-672.

Ardanari, S., \& Putra, W. (2014). Pengaruh Partisipasi Penganggaran, Asimetri Informasi, Self Esteem Dan Budget Emphasis Pada Budgetary Slack. EJurnal Akuntansi, 7(3), 700-715.

Arnold, M. C., \& Gillenkirch, R. M. (2015). Using Negotiated Budgets For Planning And Performance Evaluation: An Experimental Study. Accounting, Organizations And Society, 43, 1-16. https://doi.org/10.1016/j.aos.2015.02.002

Badan Pusat Statistik Provinsi Bali. (2018). Jumlah Wisatawan Asing Ke Indonesia Dan Bali Tahun 1969-2017. Retrieved from http://www.bali.bps.go.id.

Baerdemaeker, J. De, \& Bruggeman, W. (2015). The Impact Of Participation In Strategic Planning On Managers' Creation Of Budgetary Slack: The Mediating Role Of Autonomous Motivation And Affective Organisational Commitment. Management Accounting Research, 1-12. 
https://doi.org/10.1016/j.mar.2015.06.002

Colliers International Indonesia. (2018). Colliers Report Quartely Bali Hotel. Jakarta.

Etemadi, H., \& Sirghani, S. (2016). The Effect Of The Budget Slack Creation And Budget Internal Control By Managers On Maximization Of Utility Function In Budgetary Participation. International Journal Of Finance And Managerial Accounting, 1(2), 37-49.

Fatmawati, I., \& Widyaningsih, A. (2014). Pengaruh Partisipasi Anggaran Terhadap Senjangan Anggaran: Komitmen Organisasi Dan Ketidakpastian Lingkungan Sebagai Variabel Moderating. Jurnal Riset Akuntansi Dan Keuangan, 2(2), 338-351.

Garbers, Y., \& Konradt, U. (2014). The Effect Of Financial Incentives On Performance: A Quantitative Review Of Individual And Team-Based Financial Incentives. Journal Of Occupational And Organiational Psychology, 87, 102-137. https://doi.org/10.1111/joop.12039

Kahar, S., Rohman, A., \& Chariri, A. (2016). Participative Budgeting, Budgetary Slack And Job Satisfaction In The Public Sector. The Journal Of Applied Business Research, 32(6), 1663-1674. https://doi.org/10.19030/jabr.v32i6.9814

Langevin, P., \& Mendoza, C. (2013). How Can Management Control System Fairness Reduce Managers Õ Unethical Behaviours? European Management Journal, 31(3), 209-222. https://doi.org/10.1016/j.emj.2012.12.001

Lubis, A. I. (2011). Akuntansi Keperilakuan (2nd ed.). Jakarta: Salemba Empat.

Mah'd, O., Al-khadash, H., Idris, M., \& Ramadan, A. (2013). The Impact of Budgetary Participation on Managerial Performance: Evidence from Jordanian University Executives. Journal Of Applied Finance \& Banking, 3(3), 133-156.

Netra, W., \& Damayanthi, E. (2017). Pengaruh Karakter Personal, Reputasi, Dan Self Esteem Terhadap Senjangan Anggaran. E-Jurnal Akuntansi, 19(2), 1406-1435. 
Pamungkas, W., Adiputra, P., \& Sulindawati, E. (2014). Pengaruh Partisipasi Anggaran, Informasi Asimetri, Budaya Organisasi, Kompleksitas Tugas, Reputasi, Etika, Dan Self Esteem Terhadap Budgetary Slack (Studi Pada Satuan Kerja Perangkat Daerah Kabupaten Jembrana). E-Journal S1 Ak Universitas Pendidikan Ganesha, 2(1).

Panda, B., \& Leepsa, N. M. (2017). Agency theory: Review of Theory And Evidence On Problems And Perspectives. Indian Journal OfCorporate Governance, 10(1), 74-95. https://doi.org/10.1177/0974686217701467

Pratami, D., \& Erawati, A. (2016). Pengaruh Partisipasi Penganggaran Terhadap Senjangan Anggaran Dengan Penekanan Anggaran Dan Ketidakpastian Lingkungan Sebagai Pemoderasi. E-Jurnal Akuntansi, 15(2), 1565-1594.

Puspitha, D., \& Suardana, A. (2017). Faktor-Faktor Yang Mempengaruhi Senjangan Anggaran Di SKPD Kabupaten Karangasem Bali. E-Jurnal Akuntansi, 21(1), 800-829.

Ramona, F. (2016). Pengaruh Self Esteem, Budget Emphasis, Dan Locus Of Control Terhadap Slack Anggaran. Jurnal Akuntansi UDINUS, 1-16.

Raudhiah, N. (2014). Impact Of Organisational Factors On Budgetary Slack. Synergizing Knowledge On Management and Muamalahn Management and Muamalah, 978-983.

Sasongko, \& Parulian. (2015). Anggaran. Jakarta: Salemba Empat.

Setiawan, B. M., \& Ghozali, I. (2016). The Effect Of Budget Participation On Budgetary Slack In Local Government With Organizational Commitment And Environmental Uncertainty As The Moderating Variable. International Journal Of Applied Business And Economic Research, 14(10), 7099-7120.

Sharma, S., \& Agarwala, S. (2013). Contribution Of Self-Esteem And Collective Self-Esteem In Predicting Depression. Psychological Thought, 6(1), 117123. https://doi.org/10.5964/psyct.v6i1.50

Thien, T. H. (2014). Factors Affecting the Propensity to Create Budgetary Slack Evidence from Vietnamese Enterprises. Journal Of Economic Development, $22(1), 100-124$. 
Wati, S., \& Damayanthi, E. (2017). Pengaruh Partisipasi Penganggaran , Asimetri Informasi , Ketidakpastian Lingkungan Dan Budget Emphasis Pada Senjangan Anggaran. E-Journal S1 Ak Universitas Pendidikan Ganesha, 21(3), 2311-2337. https://doi.org/https://doi.org/10.24843/EJA.2017.v21.i03.p22

Wijayanthi, P., \& Widanaputra, A. A. G. . (2016). Pengaruh Partisipasi Penganggaran Pada Senjangan Dengan Kepercayaan Diri Dan Ketidakpastian Lingkungan Sebagai Pemoderasi. E-Jurnal Akuntansi, 15(1), 695-726.

Yasa, G. M., Diatmika, P. G., \& Prayudi, M. A. (2017). Pengaruh Partisipasi Anggaran, Penekanan Anggaran, Kejelasan Sasaran Anggaran, Dan Self Esteem Terhadap Senjangan Anggaran Desa Di Kecamatan Kubutambahan. E-Journal S1 Ak Universitas Pendidikan Ganesha, 8(2), 1-12.

Yeandrawita, M, R., \& Safitri, D. (2015). Pengaruh Partisipasi Anggaran, Informasi Asimetri, Kompleksitas Tugas, dan Penekanan Anggaran Terhadap Senjangan Anggaran Instansi Pemerintah Daerah. Jom FEKON, 2(2), 1-12.

Yuen, D. C., Law, P. K., \& Tayles, M. (2015). Exploring Budgetary Slack: The Influence Of Organizational Commitment And Job-Related Tension. Corporate Ownership And Control, 12(2), 615-627.

Yulianti, E. (2014). Pengaruh Partisipasi Penganggaran, Komitmen Organisasi, dan Kompleksitas Tugas Terhadap Senjangan Anggaran. Jurnal Akuntansi Universitas Negeri Padang, 2(1), 1-21. 